\title{
Pengaruh Pendapatan Asli Daerah, Dana Perimbangan, dan Lain-Lain Pendapatan Daerah yang Sah pada Belanja Daerah
}

\author{
Ni Made Arni Asari ${ }^{1}$ \\ Ketut Alit Suardana ${ }^{2}$ \\ ${ }^{1}$ Fakultas Ekonomi dan Bisnis Universitas Udayana (Unud), Bali, Indonesia \\ email: arniasari22@gmail.com/ Telp:087730532337 \\ ${ }^{2}$ Fakultas Ekonomi dan Bisnis Universitas Udayana (Unud), Bali, Indonesia
}

\begin{abstract}
ABSTRAK
Tujuan penelitian ini adalah untuk mengetahui pengaruh pendapatan asli daerah, dana perimbangan dan lain-lain pendapatan daerah yang sah pada belanja daerah. Penelitian ini dilakukan di Pemerintahan Kabupaten Badung. Penentuan sampel menggunakan teknik purposive sampling melalui kriteria-kriteria tertentu sehingga diperoleh sampel sebanyak 60 sampel. Teknik analisis yang digunakan dalam penelitian ini adalah regresi linear berganda dan uji hipotesis menggunakan t-statistik untuk menguji koefisien regresi parsial serta f-statistik untuk menguji kelayakan model penelitian dengan significance level 5\%. Selain itu juga dilakukan uji asumsi klasik yang meliputi uji normalitas, uji multikolinieritas, uji autokorelasi dan uji heteroskedastisitas. Hasil analisis menunjukkan bahwa pendapatan asli daerah, dana perimbangan dan lain-lain pendapatan daerah yang sah secara simultan berpengaruh positif pada belanja daerah. pendapatan asli daerah, dana perimbangan dan lain-lain pendapatan.
\end{abstract}

Kata Kunci: Belanja daerah, pendapatan asli daerah, dana perimbangan

\begin{abstract}
The purpose of this study is to determine the effect of local revenue, balance funds and other legitimate local revenue on regional expenditure. This research was conducted in Badung Regency Government. Determination of the sample using purposive sampling technique through certain criteria so that obtained sample of 60 samples. The analysis technique used in this research is multiple linear regression and hypothesis test using $t$ statistic to test partial regression coefficient and $f$-statistic to test the feasibility of research model with significance level 5\%. In addition, the classical assumption test included normality test, multicollinearity test, autocorrelation test and heteroscedasticity test. The results of the analysis show that local revenues, equity funds and other legitimate local revenue simultaneously have a positive effect on local spending. local revenue, balance funds and other income.
\end{abstract}

Keywords: Rregional expenditure, local revenue, balancing fund

\section{PENDAHULUAN}

Pembangunan daerah sebagai bagian dari integral pembangunan nasional dilaksanakan berdasarkan prinsip otonomi daerah dan pengaturan sumber daya nasional yang memberikan kesempatan bagi peningkatan demokrasi dan kinerja daerah untuk meningkatkan kesejahteraan masyarakat. Adisasmita (2011:3) 
otonomi yang diberikan kepada daerah kabupaten dan kota dilaksanakan dengan memberikan kewenangan yang luas, nyata dan bertanggungjawab kepada pemerintah daerah secara proporsional dan pemanfaatan sumber daya nasional yang berkeadilan serta perimbangan keuangan pusat dan daerah. Terkait dengan belanja daerah maka dalam pelaksanaan otonomi daerah tersebut pemerintah daerah harus memiliki wewenang dalam menggali sumber keuangan sendiri dan didukung oleh dana perimbangan keuangan pemerintah pusat dan daerah serta kabupaten/ kota yang merupakan dana yang dimiliki untuk dikelola dalam belanja daerah.

Diberlakukannya otonomi daerah memberikan kesempatan pemerintah daerah untuk mengembangkan potensi daerah, dalam pengembangan potensi daerah tersebut maka perlu meningkatkan anggaran belanja daerah, yang terdiri dari belanja modal dan belanja pegawai. Pelaksanaan kebijakan otonomi daerah didukung pula oleh perimbangan keuangan antara pemerintah pusat dan pemerintah daerah sebagai mana tertuang dalam UU No. 33 Tahun 2004 tentang Perimbangan Keuangan antara Pemerintah Pusat - Daerah. Dalam UU tersebut yang dimaksudkan dengan perimbangan antara pemerintah pusat dan daerah adalah adanya suatu sistem pembiayaan pemerintah, yang mencakup pembagian keuangan antara Pemerintah Pusat dan Daerah serta pemerataan daerah secara proporsional, demokratis, adil, dan transparan dengan memperhatikan potensi, kondisi, dan kebutuhan di setiap daerah. Wong (2004) menunjukkan bahwa pembangunan infrastruktur industri mempunyai dampak yang nyata terhadap kenaikan pajak daerah. Dengan terpenuhinya fasilitas publik maka masyarakat 
merasa nyaman dan dapat menjalankan usahanya dengan efisien dan efektif sehingga pada akhirnya akan meningkatkan partisipasi publik dalam pembangunan. Semakin tinggi tingkat investasi modal diharapkan mampu meningkatkan kualitas layanan publik dan pada gilirannya mampu meningkatkan tingkat partisipasi publik terhadap pembangunan yang tercermin dari adanya peningkatan PAD (Mardiasmo, 2002). Pemberian otonomi yang lebih besar akan memberikan dampak yang lebih besar bagi pertumbuhan ekonomi, hal inilah yang mendorong daerah untuk mengalokasikan secara lebih efisien berbagai potensi lokal untuk kepentingan pelayanan publik (Lin dan Liu, 2000; Mardiasmo, 2002; Wong, 2004).

Berdasarkan Permendagri No. 37 Tahun 2014 tentang Pedoman Penyusunan Anggaran Pendapatan dan Belanja Daerah, Anggaran Pendapatan dan Belanja Daerah terdiri atas beberapa komponen, yaitu: pendapatan daerah yang dianggarkan dalam APBD merupakan perkiraan yang terukur secara rasional dan memiliki kepastian serta dasar hukum penerimanya.Komponen Pendapatan Daerah terdiri atas Pendapatan Asli Daerah (PAD), Dana Perimbangan, dan LainLain Pedapatan Daerah Yang Sah. Halim (2007:322) menyatakan bahwa Belanja Daerah adalah kewajiban pemerintah mengurangi nilai kekayaan bersih.Belanja Daerah harus digunakan untuk pelaksanaan urusan pemerintahan yang menjadi kewenangan pemerintah provinsi dan pemerintah kabupaten/kota yang terdiri dari urusan wajib dan urusan pilihan yang ditetapkan dengan peraturan perundangundangan. Belanja penyelenggaraan urusan wajib diprioritaskan untuk melindungi dan meningkatkan kualitas kehidupan masyarakat dalam upaya memenuhi 
kewajiban daerah yang diwujudkan dalam bentuk peningkatan pelayanan dasar, pendidikan, kesehatan, fasilitas sosial dan fasilitas umum yang layak serta mengembangkan sistem jaminan sosial.Komponen Belanja Daerah terdiri atas Belanja Tidak Langsung dan Belanja Langsung.

Pembiayaan Daerah adalah semua penerimaan yang perlu dibayar kembali dan/atau pengeluaran yang akan diterima kembali, baik pada tahun anggaran yang bersangkutan maupun pada tahun-tahun anggaran berikutnya. Komponen Pembiayaan Daerah adalah Penerimaan Pembiayaan, Pengeluaran Pembiayaan, Sisa Lebih Pembiayaan (SILPA) Tahun Berjalan.

Struktur APBD antara pendapatan, belanja dan pembiayaan.Selisih antara anggaran pendapatan daerah dengan anggaran Belanja Daerah mengakibatkan terjadinya suplus atau defisit APBD.Surplus anggaran terjadi apabila anggaran pendapatan daerah diperkirakan lebih besar dari anggaran Belanja Daerah.Defisit anggaran terjadi apabila anggaran pendapatan daerah diperkirakan lebih kecil dari anggaran Belanja Daerah. Surplus dalam APBD digunakan untuk pembayaran pokok utang, penyertaan modal (investasi) daerah, pemberian pinjaman kepada pemerintah pusat/daerah, transfer ke Dana Cadangan dan Sisa Lebih Tahun Anggaran Berjalan yang disebut Pengeluaran Pembiayaan. Defisit dalam APBD ditetapkan pembiayaan untuk menutup defisit tersebut yang diantaranya bersumber dari Sisa Lebih Perhitungan Anggaran Lalu, penggunaan Dana Cadangan, penerimaan pinjaman, hasil penjualan kekayaan daerah yang dipisahkan, dan penerimaan kembali pemberian pinjaman atau penerimaan 
piutang. Ringkasan Laporan Realisasi Anggaran Pendapatan dan Belanja Daerah Kabupaten Badung

Berdasarkan data realisasi APBD yang diperoleh dari Badan Pengelola Keuangan dan Aset Daerah Kabupaten Badung di tahun 2012-2016 jumlah realisasi PAD yaitu sebesar Rp. 13.439.009.153.707,40 lebih besar dari jumlah anggaran sebesar Rp. 12.262.986.801.142,10. Jumlah realisasi Dana Perimbangan sebesar Rp. 2.202.739.788.440,00 lebih besar dari jumlah anggaran sebesar Rp. 2.133.803.514.807,20. Jumlah realisasi Lain-Lain Pendapatan Daerah Yang Sah yaitu Rp. 1.456.999.549.487,55 dari jumlah anggaran Rp. 1.463.482.853.963,64.

Anggaran sektor publik pemerintah daerah dalam APBD sebenarnya merupakan output pengalokasian sumberdaya. Adapun pengalokasian sumberdaya merupakan permasalahan dasar dalam penganggaran sektor publik (Key 1940 dalam Fozzard, 2001). Dengan sumber daya yangterbatas, Pemerintah Daerah harus dapat mengalokasikan penerimaan yang diperolehuntuk belanja daerah yang bersifat produktif. Bagaimana pemerintah daerah mengalokasikan sumber dayayang dimilikinya merupakan pertanyaan penelitian yang menarik sejaklama. Peneliti terdahulu menggunakan berbagai pendekatan untuk menjelaskan perilaku pemerintah daerah dalam mengalokasikan dana yangdimilikinya, baik dana yang bersumber dari transfer pemerintah diatasnya ataupun dari pendapatannya sendiri. Pemerintah daerah bisa merespon transfer dari pemerintah pusat secara simetris dan tidak simetris (Gamkhar \& Oates, 1996). Beberapa peneliti menemukan bahwa respon pemerintah daerah berbeda untuk transfer dan pendapatan sendiri (seperti pajak). Artinya,ketika penerimaan daerah berasal dari transfer, maka 
stimulus atasbelanja yang ditimbulkan berbeda dengan stimulus yang muncul daripendapatan daerah (terutama pajak daerah). Ketika respon (belanja)daerah lebih besar terhadap transfer, maka disebut flypaper effect (Oates, 1999). Flypaper effect adalah suatu fenomena pada suatu kondisi ketika pemerintah daerah merespon belanja daerahnya lebih banyak berasal dari transfer daripada pendapatan dari asli daerahnya sendiri sehingga akan mengakibatkan pemborosan dalam belanja daerah. Studi Legrensi dan Milas (2001) di Italia menemukan bukti empiris bahwa dalam jangka panjang transfer berpengaruh terhadap belanja daerah.

Dalam literatur ekonomi dan keuangan daerah, hubungan pendapatandan belanja daerah didiskusikan secara luas sejak akhir dekade 1950-an dan berbagai hipotesis tentang hubungan tersebut diujisecara empiris (Chang \& Ho, 2002). Sebagian studi menyatakan bahwa pendapatan mempengaruhi belanja, sementara sebagian lainnya menyatakan bahwa belanjalah yang mempengaruhi pendapatan (Aziz,2000; dan Doi, 1998). Pembangunan daerah sangat bergantung dari Pendapatan Asli Daerah (PAD) dan kemampuan daerah tersebut untuk mengatur keuangan daerah. PAD merupakan semua penerimaan daerah yang berasal dari sumber ekonomi asli daerah.Pendapatan Asli Daerah (PAD) merupakan pendapatan daerah yang bersumber dari hasil Pajak Daerah, Retribusi Daerah, Hasil Pengelolaan Kekayaan Daerah Yang Dipisahkan, danLain-Lain Pendapatan Asli Daerah Yang Sah. Pendapatan Asli Daerah (PAD) sangat berperan penting dalam menentukan kinerja keuangan daerah dan kemandirian daerah karena salah satu indikator kemandirian suatu daerah dapat diukur melalui peningkatan 
Pendapatan Asli Daerah (PAD) setiap tahunnya. Semakin besar kontribusi yang diberikan Pendapatan Asli Daerah (PAD) terhadap APBD dapat menunjukkan semakin kecil ketergantungan Pemerintah Daerah terhadap Pemerintah Pusat.

Menurut Undang - Undang Nomor 34 Tahun 2004 tentang Perimbangan Keuangan Pemerintah Pusat dan Daerah, yang dimaksud dengan perimbangan keuangan Pusat dan Daerah adalah suatu sistem pembiayaan dalam rangka negara kesatuan yang mencakup pembagian keuangan pemerintah pusat dan daerah serta pemerataan proporsional, demokratis, adil dan transparan yang memperhatikan potensi, kondisi dankebutuhan daerah sejalan dengan kewajiban dan pembagian kewenanganserta tata cara penyelenggaraan kewenangan tersebut, termasuk pengeloladan pengawasan keuangan. Darise (2008:137) menyatakan bahwa Dana Perimbangan adalah dana yang bersumber dari pendapatan APBN yang dialokasikan kepala daerah untuk mendanai kebutuhan daerah dalam rangka pelaksanaan desentralisasi bertujuan untuk menciptakan keseimbangan keuangan antara pemerintah pusat dan pemerintah daerah dan antara pemerintah daerah.Dana Perimbangan terdiri atas Dana Bagi Hasil (DBH), Dana Alokasi Umum (DAU), dan Dana Alokasi Khusus (DAK). Lain-Lain Pendapatan Daerah Yang Sah terdiri dari pendapatan Hibah, Pendapatan Dana Darurat, Dan Pendapatan Lainnya.

Munculnya teori kontijensi dalam akuntansi pemerintahan berawal dari adanya keinginan untuk melakukan suatu reformasi terhadap sistem akuntansi pemerintahan dari sistem akuntansi tradisional menjadi sistem akuntansi yang lebih informatif. Sistem yang lebih informatif akan tertuju pada pasokan informasi 
Ni Made Arni Asari dan Ketut Alit Suardana. Pengaruh...

yang komprehensif dan dapat diandalkan serta menyediakan dasar untuk kontrol keuangan pada kegiatan pemerintah. Teori kontinjensi dapat digunakan untuk menganalisis desain dan sistem akuntansi manajemen untuk memberikan informasi yangdapat digunakan perusahaan untuk berbagai macam tujuan (Otley, 1978). Teori kontinjensi diadopsi untuk mengevaluasi keefektifan partisipasi penyusunan anggaran terhadap kinerja aparat pemerintah daerah. Para peneliti telah mengemukakan bahwa keefektifan penggangaran partisipatif tergantung pada faktor-faktor kontekstual organisasional dan sifat psikologi karyawan (Chenhall, 1989 dalam Nazaruddin, 1998). Penggunaan teori kontinjensi dalam pengembangan sistem akuntansi manajemen akan tergantung pada lingkungan, organisasi dan gaya pembuat keputusan (Gordon dan Miller, 1976).

Anggaran merupakan implementasi dari rencana yang telah ditetapkan perusahaan. Anggaran juga merupakan proses pengendalian manajemen yang melibatkan komunikasi dan interaksi formal di kalangan para manajer dan karyawan dan merupakan pengendalian manajemen atas operasional perusahaan/organisasi pada tahun berjalan. Program atau strategic plan yang telah disetujui pada tahap sebelumnya, merupakan titik awal dalam mempersiapkan anggaran.Anggaran menunjukkan jabaran dari program dengan menggunakan informasi terkini.

Menurut Robert Anthony dan Vijay Govindarajan (2002), anggaran merupakan alat yang utama dalam perencanaan jangka pendek yang efektif dan pengendalian dalam organisasi. Sebuah anggaran operasi biasanya dalam satu tahun dan menyatakan rencana pendapatan biaya untuk tahun yang bersangkutan. 
Anggaran mempunyai karakteristik sebagai berikut : 1. Anggaran memperkirakan keuntungan yang potensial dari unit perusahaan. 2. Biasanya meliputi waktu selama satu tahun. 3. Sekali disetujui, anggaran hanya dapat diubah dalam kondisi tertentu. 4. Dinyatakan dalam istilah moneter, walaupun jumlah moneter mungkin didukung dengan jumlah non-moneter (contoh: unit yang terjual atau diproduksi). 5. Usulan anggaran diperiksa dan disetujui oleh pejabat yang lebih tinggi dari pembuat anggaran. 6. Secara berkala kinerja keuangan aktual dibandingkan dengan anggaran dan perbedaannya dianalisis dan dijelaskan.

Desentralisasi fiskal yang telah terwujud dalam bentuk keleluasaan Pemerintah daerah dalam mengalokasikan dana desentralisasi semestinya mampu meningkatkan efisiensi dan efektifitas belanja daerah, khususnya untuk mendorong pertumbuhan ekonomi yang telah menjadi tugas/fungsi daerah. Diberikannya kewenangan fiskal kepada sebuah daerah otonom didasarkan kepada prinsip agar alokasi sumber daya lebih efisien dan efektif. Pemerintah Daerah yang lebih dekat ke masyarakat diasumsikan lebih tahu kebutuhan masyarakat dibandingkan dengan Pemerintah Pusat yang jauh. Sehingga alokasi sumber daya yang dilakukan oleh Pemerintah daerah akan lebih responsif dan menjawab kebutuhan masyarakat. Oleh karena itu, anggaran belanja daerah akan tidak logis jika proporsi anggarannya lebih banyak untuk belanja rutin (Abimanyu, 2005).

Realisasi anggaran belanja dilaporkan sesuai dengan klasifikasi yang ditetapkan dalam dokumen anggaran. Akuntansi belanja disusun selain untuk memenuhi kebutuhan pertanggung jawaban sesuai dengan ketentuan, juga dapat 
Ni Made Arni Asari dan Ketut Alit Suardana. Pengaruh...

dikembangkan untuk keperluan pengendalian manajemen untuk mengukur efektivitas danefisiensi belanja suatu daerah. Mahsun dkk, (2011:96) menyatakan bahwa klasifikasi belanja daerah dapat didasarkan atas urusan pemerintahan dan program atau kegiatan. Permendagri No 64 tahun 2013 tentangPenerapan Standar Akuntansi Pemerintahan berbasis Akrual pada Pemerintah Daerah diungkapkan pengertian belanja daerah yaitu belanja daerah adalah kewajiban pemerintah daerah yang diakui sebagai pengurang nilaikekayaan bersih.

Anggaran Pendapatan dan Belanja Daerah (APBD), adalah rencana keuangan tahunan pemerintah daerah di Indonesia yang disetujui oleh Dewan Perwakilan Rakyat Daerah. APBD merupakan dasar pengelolaankeuangan daerah dalam masa 1 (satu) tahun anggaran yang terhitung mulai tanggal 1 Januari sampai dengantanggal 31 Desember (Pemendagri No. 37 Tahun 2014). Analisis belanja daerah sangat penting dilakukan untuk mengevaluasi apakah pemerintah telah menggunakan APBD secara sekonomis, efisisen dan efektif. Mahmudi (2010:156) menyatakan bahwa analisis belanja daerah digunakan untuk melihat sejauh mana pemerintah daerahtelah melakukan efisiensi anggaran, menghindari pengeluaran yang tidak perlu dan pengeluaran yang tidak tepatsasaran.

Pendapatan daerah yang diperoleh baik dari pendapatan asli daerah maupun dana perimbangan tentunyadigunakan oleh pemerintah daerah untuk membiayai belanja daerah. Belanja daerah dipergunakan dalam rangka mendanai pelaksanaan urusan pemerintah yang menjadi kewenangan Provinsi atau Kabupaten/Kota yang terdiri dari urusan wajib, urusan pilihan dan urusan yang 
penanganannya dalam bidang tertentu yang dapat dilaksanakan bersama antara Pemerintah Pusat dan Pemerintah Daerah.

Belanja penyelenggaraan urusan wajib diprioritaskan untuk melindungi dan meningkatkan kualitas kehidupan masyarakat dalam upaya memenuhi kewajiban daerah yang diwujudkan dalam bentuk peningkatan pelayanan dasar, pendidikan, kesehatan, fasilitas sosial dan fasilitas umumyang layak serta mengembangkan sistem jaminan sosial. Dalam rangka memudahkan penilaian kewajaran biaya suatu program atau kegiatan, belanja menurut kelompok belanja terdiri dari belanja tidak langsung dan belanja langsung. Belanja tidak langsung merupakan belanja yang tidak memiliki keterkaitan secara langsung dengan pelaksanaan program dan kegiatan, terdiri dari belanja pegawai, belanja bunga, subsidi, hibah, bantuan sosial, belanja bagi hasil, bantuan keuangan dan belanjatidak terduga. Sedangkan belanja langsung merupakan belanja yang memiliki keterkaitan secara langsung dengan program dan kegiatan yang meliputi belanja pegawai, belanja barang dan jasa serta belanja modal.

Menurut Yani (2008:44), Pendapatan Asli Daerah (PAD) adalah penerimaan yang diperoleh daerah dari sumber-sumber dalam wilayahnya sendiri yang dipungut berdasarkan peraturan daerah sesuai dengan peraturan perundangundangan yang berlaku. Menurut Undang - Undang No.33 Tahun 2004 adalah pendapatan yang dipungut berdasarkanperaturan perundang-undangan yang terdiri dari pajak daerah, retribusi daerah, pengelolaan kekayaan daerah yang dipisahkan dan lain-lain pendapatan yang sah. Tujuan dari PAD adalah untuk memberikan 
Ni Made Arni Asari dan Ketut Alit Suardana. Pengaruh...

kewenangankepada pemerintah daerah untuk mendanaipelaksanaan otonomi daerah sesuai denganpotensi daerah sebagai perwujudan desentralisasi.

Berdasarkan pasal 79 Undang-Undang Nomor 22 Tahun 1999 tentang Pemerintahan Daerah dapat disimpulkan PAD adalah sesuatu yang diperoleh Pemerintah Daerah yang dapat diukur dengan uang karena kewenangan (otoritas) yang diberikan masyarakat dapat berupa hasil pajak daerah dan retribusi daerah, hasil perusahaan milik daerah dan pengelolaan kekayaan daerah serta lain-lain pendapatan daerah yang sah. Dari beberapa komponen PAD tersebut, maka yang perlu mendapatkan perhatian adalah pajak dan retribusi daerah, karena kedua jenis PAD ini baik secara langsung maupun tidak langsung akan membebani rakyat.

Terkait dengan dana perimbangan (transfer pemerintah pusat), Holtzet al (1994) menyatakan bahwa terdapat keterkaitan sangat erat antara transfer dari pemerintah pusat dengan belanja pemerintah daerah. Dana Perimbangan juga merupakan salah satu sumber penerimaan daerah yang memiliki kontribusi besar terhadap sturktur APBD. Dalam UU No.33/ 2004 disebutkan Dana Perimbangan adalah dana yang bersumber dari pendapatan APBN yang dialokasikan kepada Daerah untuk mendanai kebutuhan Daerah dalam rangka pelaksanaan Desentralisasi. Perimbangan keuangan antara Pemerintah dan Pemerintahan Daerah adalah suatu sistem pembagian keuangan yang adil, proporsional, demokratis, transparan, dan efisien dalam rangka pendanaan penyelenggaraan Desentralisasi, dengan mempertimbangkan potensi, kondisi, dan kebutuhan daerah, serta besaran pendanaan penyelenggaraan Dekonsentrasi dan Tugas Pembantuan.Dana Perimbangan memiliki peranan yang besar sebagai sumber 
pembiayaan pembangunan dan pada akhirnya mampu mendorong pertumbuhan ekonomi di daerah.

Menurut Permendagri No.32 Tahun 2008, dalam rangka pelaksanaan desentralisasi, kepada daerah diberikan Dana perimbangan melalui APBN yang bersifat transfer dengan prinsip money follows function. Salah satu tujuan pemberian Dana perimbangan tersebut adalah untuk mengurangi kesenjangan fiskal antara pemerintah dengan daerah dan antar daerah, serta meningkatkan kapasitas daerah dalam menggali potensi ekonomi daerah.UU No.33 Tahun 2004 pada Pasal 1 ayat 19, menjelaskan dana perimbangan adalah dana yang bersumber dari pendapatan APBN yang dialokasikan kepada daerah untuk mendanai kebutuhan daerah dalam rangka pelaksanaan desentralisasi. Dan Pasal 10 ayat 1 menjelaskan dana perimbangan terdiri atas: dana bagi hasil, dana alokasi umum, dan dana alokasi khusus.

Dana bagi hasil adalah dana yang berasal dari pendapatan APBN yang dialokasikan kepada daerah berdasarkan angka persentase untuk mendanai kebutuhan daerah dalam rangka pelaksanaan desentralisasi. Dana bagi hasil merupakan himpunan atas hasil setoran pendapatan pajak dan nonpajak dari daerah yang kemudian dibagikan kembali ke daerah melalui persentase. Dana bagi hasil bersifat proporsional untuk setiap daerah, dalam arti penerimaan DBH setiap daerah tidak sama, tergantung pada kontribusi setiap daerah dalam meningkatkan pendapatan negara. DBH merupakan sumber pendapatan daerah yang cukup potensial dan merupakan salah satu modal dasar pemerintah daerah dalam mendapatkan dana pembangunan dan memenuhi belanja daerah yang bukan 
berasal dari PAD selain DAU dan DAK. Pola bagi hasil penerimaan tersebut dilakukan dengan persentase tertentu yang didasarkan atas daerah penghasil. Penerimaan DBH pajak bersumber dari : Pajak Bumi dan Bangunan (PBB), Bea Perolehan Hak atas Tanah dan Bangunan (BPHTB), Pajak Penghasilan ( $\mathrm{PPh})$ Pasal 25, PPh Pasal 29 Wajib Pajak Orang Pribadi Dalam Negeri, dan PPh Pasal 21. Sedangkan penerimaan DBH nonpajak berasal dari sumber daya alam bersumber dari: kehutanan, pertambangan umum, perikanan, pertambangan minyak bumi, pertambangan gas bumi, pertambangan panas bumi (UU No. 33 Tahun 2004).

Dana alokasi umum adalah dana yang bersumber dari pendapatan APBN yang dialokasikan dengan tujuan pemerataan kemampuan keuangan antar-daerah untuk mendanai kebutuhan daerah dalam rangka pelaksanaan desentralisasi. Fungsi DAU sebagai faktor pemerataan kapasitas fiskal dengan jumlah keseluruhan yang ditetapkan sekurang - kurangnya 26\% (dua puluh enam persen) dari pendapatan dalam negeri neto yang ditetapkan dalam APBN. DAU suatu daerah ditentukan atas besar kecilnya celah fiskal (fiscal gap) suatu daerah, yang merupakan selisih antara kebutuhan daerah (fiscal need) dengan potensi daerah (fiscal capacity). Dana alokasi umum digunakan untuk menutup celah yang terjadi karena kebutuhan daerah melebihi dari potensi penerimaan daerah yang ada.

Dana alokasi khusus adalah dana yang bersumber dari pendapatan APBN yang dialokasikan kepada daerah tertentu dengan tujuan untuk membantu mendanai kegiatan khusus yang merupakan urusan daerah dan sesuai dengan prioritas nasional, khususnya untuk membiayai kebutuhan sarana dan prasarana 
pelayanan dasar masyarakat yang belum mencapai standar tertentu atau untuk mendorong percepatan pembangunan daerah. Pelayanan dasar masyarakat meliputi pendidikan, kesehatan, infrastruktur, dan prasarana pemerintah daerah.Sementara itu, untuk bidang teknis tertentu, seperti bidang kelautan dan perikanan, bidang pertanian, bidang lingkungan hidup, dan lain-lain.

Sesuai Pasal 41 UU No. 33 Tahun 2004, pemerintah daerah penerima DAK wajib menganggarkan dan menyediakan dana sekurang- kurangnya $10 \%$ dari alokasi DAK dalam APBD. Meski demikian, wilayah dengan pengeluaran lebih besar dari penerimaan tidak perlu menyediakan dana penyesuaian. Tetapi perlu diketahui bahwa tidak semua daerah menerima DAK karena DAK bertujuan untuk pemerataan dan untuk meningkatkan kondisi infrastruktur fisik yang dinilai sebagai prioritas nasional.

Menurut UU Nomor 33 Tahun 2004 tentang perimbangan keuangan antara pemerintah pusat dan daerah, menjelaskan tentang pendapatan asli daerah yang sah, disediakan untuk menganggarkan penerimaan daerah yang tidak termasuk dalam jenis pajak daerah, dan hasil pengelolaan kekayaan daerah yang dipisahkan. Peraturan Pemerintah Nomor 58 Tahun 2005 tentang pengelolaan keuangan daerah, menyatakan bahwa lain-lain pendapatan daerah yang sah merupakan seluruh pendapatan daerah selain PAD dan dana perimbangan, yang meliputi hasil penjualan aset daerah yang tidak dipisahkan, penerimaan jasa giro, pendapatan bunga deposito, tuntutan ganti kerugian daerah dan komisi, potongan dan selisih nilai tukar rupiah. 
Ni Made Arni Asari dan Ketut Alit Suardana. Pengaruh...

Lain-lain pendapatan daerah yang sah menurut UU 32/ 2004 pasal 164 ayat 1 tentang pemerintah daerah adalah seluruh pendapatan daerah selain PAD, Dana Perimbangan, yang meliputi hibah, dana darurat, dan lain-lain pendapatan yang ditetapkan pemerintah. Setiap belanja daerah yang akan dikeluarkan oleh pemerintah daerah terlebih dahulu dianggarkan dalam APBD. Dalam Permendagri No. 13 tahun 2006 Pasal 122 dinyatakan bahwa pengeluaran tidak dapat dibebankan pada anggaran belanja jika untuk pengeluaran tersebut tidak tersedia atau tidak cukup tersedia dalam APBD. PAD, dana perimbangan dan lain-lain pendapatan daerah yang sah merupakan sumber pendapatan daerah. Ini berarti pemerintah daerah akan menyesuaikan belanja daerah yang akan dikeluarkan dengan PAD yang diterima, dana perimbangan yang ditransfer dari pusat dan lainlain pendapatan daerah yang sah.

Menurut Yani (2008:44), Pendapatan Asli Daerah (PAD) adalah penerimaan yang diperoleh daerah dari sumber-sumber dalam wilayahnya sendiri yang dipungut berdasarkan peraturan daerah sesuai dengan peraturan perundangundangan yang berlaku. Menurut Undang-Undang No.33 Tahun 2004 adalah pendapatan yang dipungut berdasarkan peraturan perundang-undangan yang terdiri dari pajak daerah, retribusi daerah, pengelolaan kekayaan daerah yang dipisahkan dan lain-lain pendapatan yang sah..

Studi tentang pengaruh pendapatan daerah (local own source revenue) terhadap pengeluaran daerah sudah banyak dilakukan (misalnya Aziz et al, 2000; Blackley, 1986; Joulfaian \& Mokeerjee, 1990; Legrenzi \& Milas, 2001; von Furstenberg et al, 1986). Hipotesis yang menyatakan bahwa pendapatan daerah 
(terutama pajak) akan mempengaruhi anggaran belanja pemerintah daerah dikenal dengan nama tax-spend hypothesis (Aziz et al, 2000; Doi, 1998; von Furstenberg et al, 1986). Penelitian yang dilakukan juga oleh Ferdian (2013), Wulansari (2015), dan Adventino (2016) menyatakan bahwa PAD berpengaruh positif pada belanja daerah. Semakin tinggi pendapatan daerah yang berasal dari pendapatan asli daerah, maka semakin tinggi pula pengeluaran untuk belanja daerah. Pendapatan asli daerah akan mempengaruhi anggaran belanja pemerintah daerah. Semakin banyak PAD yang di dapat semakin memungkinkan daerah tersebut untuk memenuhi kebutuhan belanjanya sendiri, tanpa harus bergantung pada pemerintah pusat.

$\mathrm{H}_{1}$ : Pendapatan Asli Daerah berpengaruh positif pada Belanja Daerah.

Dalam UU No. 33/2004 disebutkan dana perimbangan adalah dana yang bersumber dari pendapatan APBN yang dialokasikan kepada daerah untuk mendanai kebutuhan daerah dalam rangka pelaksanaan Desentralisasi.Dana Perimbangan terdiri atas Dana Bagi Hasil (DBH), Dana Alokasi Umum (DAU), dan Dana Alokasi Khusus (DAK). Dana perimbangan merupakan dana alokasi dari pemerintah pusat yang berfungsi untuk mendorong otonomi daerah. untuk beberapa daerah yang memiliki pendapatan asli daerah relatif kecil, jalannya roda pemerintahan akan bergantung pada tersedianya dana perimbangan (dana transfer).

Ferdian (2013), Wulansari (2015) dan Adventino (2016) mengemukakan hasil penelitiannya yang menyatakan bahwa dana perimbangan berpengaruh 
positif terhadap belanja daerah yang artinya jika dana perimbangan meningkat maka belanja daerah juga meningkat.

$\mathrm{H}_{2}$ : Dana perimbangan berpengaruh positif pada belanja daerah.

Peraturan Pemerintah Nomor 58 Tahun 2005 tentang pengelolaan keuangan daerah, menyatakan bahwa lain-lain pendapatan daerah yang sah merupakan seluruh pendapatan daerah selain PAD dan dana perimbangan, yang meliputi hasil penjualan aset daerah yang tidak dipisahkan, penerimaan jasa giro, pendapatan bunga deposito, tuntutan ganti kerugian daerah dan komisi, potongan dan selisih nilai tukar rupiah.Peningkatan penerimaan lain-lain pendapatan daerah yang sah akan meningkatkan alokasi belanja daerah pemerintah daerah dalam APBD.

Penelitian yang dilakukan oleh Ferdian (2013), Igna (2015) dan Adventino (2016) menunjukkan bahwa Lain-Lain Pendapatan Daerah Yang Sah berpengaruh positif terhadap belanja daerah yang artinya jika lain-lain pendapatan daerah yang sah meningkat maka belanja daerah juga akan meningkat. Berdasarkan uraian tersebut, maka hipotesis yang dapat dirumuskan dalam penelitian ini adalah:

$\mathrm{H}_{3}$ : Lain-lain pendapatan daerah yang sah berpengaruh positif pada belanja daerah

\section{METODE PENELITIAN}

Penelitian ini menggunakan pendekatan kuantitatif yang dinyatakan dalam angkaangka. Variabel bebas yang digunakan terdiri dari pendapatan asli daerah $\left(\mathrm{X}_{1}\right)$, dana perimbangan $\left(\mathrm{X}_{2}\right)$, dan lain-lain pendapatan daerah yang sah $\left(\mathrm{X}_{3}\right)$. Variabel terikat dalam penelitian ini adalah belanja daerah (Y). Penelitian ini dilakukan pada Badan Pengelola Keuangan dan Aset Daerah (BPKAD) Kabupaten Badung. 
Populasi dalam penelitian ini adalah belanja daerah di Kabupaten Badung tahun 2012-2016. Sampel dalam penelitian ini ditentukan dengan menggunakan teknik purposive sampling yaitu teknik penentuan sampel dengan pertimbangan tertentu (Sugiyono, 2016:85). Pertimbangan tersebut yaitu anggaran pendapatan dan belanja daerah tahun 2012-2016.

Metode pengumpulan data yang digunakan dalam penelitian ini adalah metode observasi non partisipan, yaitu peneliti melakukan observasi sebagai pengumpul data tanpa ikut terlibat dan hanya sebagai pengamat independen. Pengumpulan data dalam penelitian ini dilakukan dengan cara mengamati, mengolah dan mencatat data yang bersumber dari BPKAD Kabupaten Badung.

Analisis regresi linier berganda dilakukan menggunakan aplikasi software Statistical Package for Social Science (SPSS). Analisa ini digunakan untuk mengetahui pengaruh pendapatan asli daerah $\left(\mathrm{X}_{1}\right)$, dana perimbangan $\left(\mathrm{X}_{2}\right)$, dan lain-lain pendapatan daerah yang sah $\left(\mathrm{X}_{3}\right)$ terhadap belanja daerah $(\mathrm{Y})$. Persamaan regresi penelitian ini adalah:

$Y=\alpha+\beta_{1} X_{1}+\beta_{2} X_{2}+\beta_{3} X_{3}+e$

Keterangan:

$\mathrm{Y} \quad=$ Belanja Daerah

$\alpha \quad=$ Konstanta

$\beta_{1}-\beta_{3}=$ Koefisien regresi untuk $X_{1}, X_{2}, X_{3}$

$\mathrm{X}_{1} \quad=$ Pendapatan asli daerah

$\mathrm{X}_{2} \quad=$ Dana Perimbangan

$\mathrm{X}_{3} \quad=$ Lain-lain pendapatan daerah yang sah

$\mathrm{e} \quad=$ Standar Error 
Ni Made Arni Asari dan Ketut Alit Suardana. Pengaruh...

\section{HASIL DAN PEMBAHASAN}

Sebagaimana lazimnya sebuah lembaga, anggota masyarakat adat ini terikat dalam suatu aturan adat yang disebut awig - awig. Keberadaan awig-awig ini sangat mengikat warganya sehingga umumnya masyarakat sangat patuh kepada adat.Oleh karena itu keberadaan Lembaga Adat ini merupakan sarana yang sangat ampuh dalam menjaring partisipasi masyarakat.Banyak program yang dicanangkan Pemerintah berhasil dilaksanakan dengan baik di daerah ini, berkat keterlibatan dan peran serta lembaga adat yang ada.nformasi karakteristik variabel penelitian, antara lain nilai minimum, maksimum, mean (rata-rata) dan standar deviasi disajikan dengan menggunakan statistik deskriptif yang ditunjukkan pada Tabel 1.

Tabel 1.

Hasil Statistik Deskriptif

\begin{tabular}{|c|c|c|c|c|c|}
\hline & $\mathbf{N}$ & Minimum & Maximum & Mean & Std. Deviation \\
\hline Belanja Daerah & 60 & 3636.00 & 15498.00 & 1028.89 & 3039.777 \\
\hline $\begin{array}{l}\text { Pendapatan Asli } \\
\text { Daerah }\end{array}$ & 60 & 1198.92 & 18256.00 & 1607.01 & 3934.41 \\
\hline $\begin{array}{l}\text { Dana } \\
\text { Perimbangan }\end{array}$ & 60 & 4779.00 & 54332.00 & 2538.30 & 1344.00 \\
\hline $\begin{array}{l}\text { Lain-Lain } \\
\text { Pendapatan } \\
\text { daerah yg Sah }\end{array}$ & 60 & .00 & 40141.96 & 1070.9634 & 9246.50 \\
\hline $\begin{array}{l}\text { Valid N } \\
\text { (listwise) }\end{array}$ & 60 & & & & \\
\hline
\end{tabular}

Berdasarkan tabel di atas statistik deskriptif yang ditunjukkan adalah nilai minimum, maksimum, mean (rata-rata) dan standar deviasi adalah nilai rata rata Belanja Daerah sebesar 1028,89dengan standar deviasi sebesar 3039,777. 
Nilai minimum Belanja Daerah sebesar 3636,00 sedangkan nilai maksimum pada sampel yaitu sebesar 15498,00.

Pendapatan Asli Daerah memiliki nilai rata - rata sebesar 1607.01 dengan standar deviasi 3934.41. Nilai minimum dari Pendapatan Asli Daerah adalah sebesar 1198.92 dan nilai maksimum sebesar 18256.00

Pada tabel rata-rata Dana Perimbangan adalah 2538.30 dengan standar deviasi1344.00. Dana Perimbangan memiliki nilai minimum 4779.00sebesar serta nilai maksimum sebesar 54332.00.

Rata-rata Lain-Lain Pendapatan Daerah Yang Sah adalah 1070.9634sebesar dengan standar deviasi sebesar9246.50. Nilai Lain-Lain Pendapatan Daerah Yang Sah minimum adalah sebesar .00. Sedangkan Lain-Lain Pendapatan Daerah Yang Sah maksimum dalam penelitian ini sebesar 40141.96.

Analisis regresi linier berganda dilakukan menggunakan aplikasi software Statistical Package for Social Science (SPSS). Analisa ini digunakan untuk mengetahui pengaruh pendapatan asli daerah $\left(\mathrm{X}_{1}\right)$, dana perimbangan $\left(\mathrm{X}_{2}\right)$, dan lain-lain pendapatan daerah yang sah $\left(\mathrm{X}_{3}\right)$ terhadap belanja daerah $(\mathrm{Y})$

Tabel 2.

HasilAnalisis Regresi Linear Berganda

\begin{tabular}{|c|c|c|c|c|c|}
\hline Model & Unsta & ed Coefficients & $\begin{array}{c}\text { Standardize } \\
\text { d } \\
\text { Coefficients } \\
\text { Beta }\end{array}$ & $\mathbf{t}$ & Sig. \\
\hline (Constant) & -76937.808 & 24603.455 & & -3.127 & .003 \\
\hline $\begin{array}{l}\text { Pendapatan Asli } \\
\text { Daerah }\end{array}$ & .596 & .164 & .537 & 3.631 & .001 \\
\hline $\begin{array}{l}\text { Dana Perimbangan } \\
\text { Lain-Lain }\end{array}$ & .574 & .114 & .466 & 5.051 & .000 \\
\hline $\begin{array}{l}\text { Pendapatan Daerah } \\
\text { yg Sah }\end{array}$ & .221 & .105 & .214 & 2.107 & .038 \\
\hline
\end{tabular}


Ni Made Arni Asari dan Ketut Alit Suardana. Pengaruh...

Berdasarkan tabel tersebut diperoleh model regresi berganda yang terbentuk pada penelitian ini adalah sebagai berikut:

$$
Y=-76937.808+0.596 X 1+0.574 X 2+0.221 X 3
$$

Model ini memiliki interpretasi sebagai berikut nilai konstanta $(\alpha)$ sebesar 76937.808 menyatakan bahwa pada saat variabel independen yaitu Pendapatan Asli Daerah (PAD), Dana Perimbangan (DP), dan Lain-Lain Pendapatan Daerah Yang Sah (LLPDYS) bernilai $0\left(X_{1}=0, X_{2}=0, X_{3}=0\right)$ maka Belanja Daerah (BD) bernilai Rp-7693770405383.808 satuan.

Nilai koefisien Variabel Pendapatan Asli daerah bernilai positif sebesar 0.596 maka artinya apabila nilai Pendapatan Asli daerah naik satu satuan maka Belanja Daerah akan naik sebesar 0.596, apabila nilai Variabel Dana Perimbangan dan Lain-lain Pendapatan Dearah yg Sah dipertahankan konstan.

Nilai koefisien Variabel Dana Perimbangan bernilai positif sebesar 0.574 maka artinya apabila nilai dana Perimbangan naik satu satuan maka Belanja Daerah akan naik sebesar 0.574, apabila nilai Variabel Pendapatan Asli Daerah dan Lain-lain Pendapatan Dearah yg Sah dipertahankan konstan.

Nilai koefisien Variabel Lain-lain Pendapatan Dearah yg Sah bernilai positif sebesar 0.221 maka artinya apabila nilai Lain-lain Pendapatan Dearah yg Sah naik satu satuan maka Belanja Daerah akan naik sebesar 0.221, apabila nilai Variabel Pendapatan Daerah dan Dana Perimbangan dipertahankan konstan

Berdasarkan hasil perhitungan regresi linear berganda dapat diketahui bahwa hasil uji menunjukkan besarnya tingkat signifikansi sebesar $0,001 \leq \alpha=$ 0,05, maka $\mathrm{H}_{0}$ ditolak dan $\mathrm{H}_{1}$ diterima. Ini berarti secara parsial pendapatan asli 
daerah berpengaruh pada belanja daerah, yaitu semakin tinggi pendapatan asli daerah di Kabupaten Badung maka belanja daerah akan semakin meningkat. Hasil penelitian ini mendukung penelitian sebelumnya yang telah dilakukan oleh Ferdian (2013), Wulansari (2015), dan Adventino (2016) yang menyatakan bahwa pendapatan asli daerah berpengaruh pada belanja daerah.

Berdasarkan hasil perhitungan regresi linear berganda dapat diketahui bahwa hasil uji menunjukkan besarnya tingkat signifikansi sebesar $0,000<\alpha=$ 0,05, maka $\mathrm{H}_{1}$ diterima dan $\mathrm{H}_{0}$ ditolak. Ini berarti secara parsial pendapatan asli daerah berpengaruh pada belanja daerah, yaitu semakin tinggi pendapatan asli daerah di kabupaten badung maka belanja daerah akan semakin meningkat. Hasil penelitian ini sejalan dengan penelitian sebelumnya yang telah dilakukan oleh Ferdian (2013), Wulansari (2015), dan Adventino (2016) yang menyatakan bahwa dana perimbangan berpengaruh pada belanja daerah.

Berdasarkan hasil perhitungan regresi linear berganda dapat diketahui bahwa hasil uji menunjukkan besarnya tingkat signifikansi sebesar $0,038<\alpha=$ 0,05, maka $\mathrm{H}_{1}$ diterima dan $\mathrm{H}_{0}$ ditolak. Ini berarti secara parsial lain-lain pendapatan daerah yang sah berpengaruh pada belanja daerah, yaitu semakin tinggi lain-lain pendapatan daerah yang sah di Kabupaten Badung maka belanja daerah akan semakin meningkat. Hasil penelitian ini sejalan dengan penelitian sebelumnya yang telah dilakukan oleh Ferdian (2013), Igna (2015), dan Adventino (2016) yang menyatakan bahwa dana perimbangan berpengaruh pada belanja daerah. 
Ni Made Arni Asari dan Ketut Alit Suardana. Pengaruh...

Koefisien Determinasi $\left(\mathrm{R}^{2}\right)$ bertujuan untuk mengetahui seberapa besar variabel independen mampu menjelaskan dan mempengaruhi variabel dependen. Nilai koefisien determinasi adalah antara nol dan satu.Nilai $\mathrm{R}^{2}$ yang kecil berarti kemampuan variabel-variabel independen dalam menjelaskan variasi dependen terbatas. Nilai yang mendekati satu berarti variabel-variabel indepenen memberikan hampir semua informasi yang dibutuhkan untuk memprediksi variasi variabel dependen (Ghozali : 2009)

Persamaan yang di gunakan adalah sebagai berikut :

$\mathrm{D}=\mathrm{R}^{2} \mathrm{X} 100 \%$

$\mathrm{D}=\operatorname{Adjs} \mathrm{R}^{2} \mathrm{X} 100 \%$

Tabel 3.

HasilUji Koefisien Determinasi

\begin{tabular}{cccccc}
\hline Model & R & R Square & $\begin{array}{c}\text { Adjusted R } \\
\text { Square }\end{array}$ & $\begin{array}{c}\text { Std. Error } \\
\text { of the Estimate }\end{array}$ & Durbin-Watson \\
\hline 1 & $.966^{\mathrm{a}}$ & .933 & .930 & 80469.251 & 1.991
\end{tabular}

Sumber: Data diolah, 2018

Analisis regresi yang digunakan adalah analisis regresi berganda sehingga koefisien determinasi yang digunakan adalah Adjusted $\mathrm{R}$ square (koefisien determinasi terkoreksi). Nilai koefisien yang diperoleh adalah sebesar 0.930. Nilai determinasinya menjadi $0.930 \times 100 \%=93 \%$. Hal ini mengindikasikan bahwa Belanja Daerah dijelaskan 93\% oleh Variabel Pendapatan Daerah, Dana Perimbangan dan Lain-lain Pendapatan Dearah Yang Sah sisanya dijelaskan oleh variabel lain yang tidak dimasukkan ke dalam model.

Uji statistik F bertujuan untuk mengetahui kelayakan model regresi linier berganda sebagai alat analisis yang menguji pengaruh variable independen 
terhadap variable dependen. Pengujian dilakukan dengan menggunakan significance level $0,05(\alpha=5 \%)$.

Tabel 4.

Hasil Uji Kelayakan Model

\begin{tabular}{lllllll}
\hline Model & & Sum of Squares & df & Mean Square & F & Sig. \\
\hline \multirow{2}{*}{1} & Regression & 508526320392784 & 3 & 16950877346426132 & 261.773 & $.000^{\mathrm{b}}$ \\
& Residual & 36262242661831835 & 56 & 64754004753271140 & & \\
& Total & 54478856305461580 & 59 & & &
\end{tabular}

Sumber: Data diolah, 2018

Pada Tabel tersebut dapat dilihat nilai signifikan sebesar 0.000 atau $<0,05$ maka menunjukkan bahwa variabel independen yang digunakan yaitu Variabel Pendapatan Asli Daerah, Dana Perimbangan dan Lain-lain Pendapatan Dearah Yang Sah berpengaruh signifikan secara simultan.

Hasil penelitian menunjukkan adanya pengaruh pendapatan asli daerah terhadap belanja daerah. Ketika belanja daerah mengalami kenaikan akibat pendapatan asli daerah, diasumsikan bahwa pemerintah akan mampu mengelola asset yang dimiliki secara optimal. Hasil penelitian ini juga menunjukkan bahwa dana perimbangan serta lain-lain pendapatan daerah yang sah berpengaruh terhadap belanja daerah. Implikasi teoritis penelitian ini berkaitan dengan teori kontinjensi dan teori anggaran partisipan.

Hasil penelitian di Kabupaten Badung mengenai variabel pendapatan asli daerah, dana perimbangan dan lain-lain pendapatan daerah yang sah yang diduga mempunyai hubungan dengan belanja daerah, yang menunjukkan hubungan yang signifikan. Variabel pendapatan asli daerah, dana perimbangan dan lain-lain pendapatan daerah yang sah memberikan kontribusi terhadap variabel belanja 
Ni Made Arni Asari dan Ketut Alit Suardana. Pengaruh...

daerah. Maka dari itudiperlukan adanya peningkatan dalam pengelolaan pendapatan asli daerah, dana perimbangan dan lain-lain pendapatan daerah yang sah oleh pemerintah daerah.

\section{SIMPULAN}

Berdasarkan hasil dan pembahasan yang sudah dijelaskan sebelumnya maka dapat disimpulkan bahwa hasil pengujian secara parsial menunjukkan bahwa pendapatan asli daerah berpengaruh positif pada belanja daerah. Hasil pengujian secara parsial menunjukkan bahwa dana perimbangan berpengaruh positif pada belanja daerah. Hasil pengujian secara parsial menunjukkan bahwa lain-lain pendapatan daerah yang sah berpengaruh positif pada belanja daerah.

Berdasarkan hasil penelitian dan simpulan maka saran yang dapat diberikan adalah pemerintah perlu meningkatkan lagi pengawasan keuangan daerah serta mengenai hal-hal terkait pengetahuan tentang anggaran. Pengetahuan tentang anggaran dimaksudkan untuk menjalankan fungsi anggota dewan dalam mengawasi keuangan daerah terkait APBD semakin baik. Peneliti selanjutnya disarankan dapat mengembangkan penelitian ini dengan mengidentifikasi variabel lain yang dapat mempengaruhi belanja daerah serta menggunakan periode pengamatan dengan tahun yang terbaru.

\section{REFERENSI}

Abimanyu, Anggito. 2005. Format Anggaran Terpadu Menghilangkan Tumpang Tindih. Bapekki Depkeu.

Adisasmita, Raharjo. 2011. Pengelolaan Pendapatan dan AnggaranDaerah. Yogyakarta: Graha Ilmu.

Anthony, Robert N, Govindarajan, Vijay, 2002. Management Control System, Buku 1, Jakarta: Salemba Empat. 
Aziz, Mariam Abdul, Muzafar Shah Habibullah, W.N.W. Azman-Saini, \&M. Azali. 2000. The casual relationship between tax revenues and governement spending in Malaysia. University Putra Malaysia, Working Paper.

Blackley, P. 1986. Causality between revenues and expenditures of the size of Federal budget. Public Financequarterly.

Chang, Tsangyao \& Yuan-Hong Ho. 2002.Tax or spend, what cause what: Taiwan's experience. International Journal of Businessand Economics 1 (2), pp. 157-165.

Fozzard, Adrian. 2001. The basic budgeting problem: Approaches to resource allocation in the public sector and their implications for pro-poor budgeting. Center for Aid and Public Expenditure, Overseas Development Institute (ODI).

Gamkhar, Shama \& Wallace Oates. 1996. Asymmetries in the response to increase and decreases in intergovernmental grant: Some empirical findings.National tax Journal 49 (4), pp. 501-512.

Ghozali, Imam. 2016. Aplikasi Analisis Multivariete dengan Program SPSS 23. Cetakan VIII. Semarang: Badan Penerbit Universitas Diponogoro.

Gordon, L. A., dan Miller, D, 1976. A Contingency Framework for The Design of Accounting Information System, Accounting Organization and Society, The Accounting Review.

Halim, Abdul. 2007. Akuntansi Sektor Publik Akuntansi Keuangan Daerah, Edisi Revisi, Jakarta, Salemba Empat.

Holtz-Eakin, Douglas, Harvey S. Rosen,\& Schuyler Tilly. 1994.Intertempora Analysis of State An Local Governemnt Spending: Theoryand test. Journal of UrbanEconomics 35, pp. 159-174.

Joulfaian, D. \& R. Mookerjee. 1990. The interporal relationship between state and local government revenues and expenditure: Evidence from OECD countries.

Key, V.O. 1940. The lack of budgetary theory.American Political Science Review 34 (December), dalam Shafritz, Jay M. \& Albert C. Hyde. 1997. Classics of Public Administration. Fourth edition. Fort Worth: Harcourt Brace College Publisher. 
Ni Made Arni Asari dan Ketut Alit Suardana. Pengaruh...

Legrenzi.Gabriella \& Costas Milas. 2001. Non-linier and asymetrics adjustment in the local revenue - expenditure models: some evidence from the Italian municipalities.University of Milan.Working paper.

Mahmudi. 2010. Analisis Laporan Keuangan Pemerintah Daerah. Unit Penerbit dan Percetakan STIM YPKN,Yogyakarta.

Mahsun, Mohamad, Firma Sulistiyowati, Heribertus dan A.Purwonugroho. 2011. Akuntansi Sektor Publik. EdisiKetiga. BPFE, Yogyakarta.

Mardiasmo. 2002. Otonomi dan Manajemen keuangan Daerah. Penerbit ANDI, Yogyakarta.

Nazaruddin, Itje. 1998. Pengaruh Desentralisasi dan Karakteristik Informasi Sistem Akuntansi Manajemen terhadap Kinerja Manajerial.Jurnal RisetAkuntansi Indonesia, 1 (2), pp. 141-162.

Oates, Wallace. 1999. An essay on fiscal federalism. Journal of Economic Literature 37, pp. 1120-1149.

Otley, David. 1980. The Contingency Theory of Management Accounting: Achievement and Prognosis, Accounting and Organization Society 5.

Undang-Undang Republik Indonesia Nomor 34 Tahun 2004 Tentang Perimbangan Keuangan AntaraPusat dan Daerah.

Wong, John D. 2004. The Fiscal Impact of Economic Growth and Development on Local Government Capacity. Journal of Public Bugeting., Accounting and Financial Management. Fall. 16 (3), pp. 799-816.

Yani, Ahmad. 2008. Hubungan Keuangan Antara Pemrintah Pusat Dan Daerah.Jakarta : PT Raja Grafindo. 